\title{
Meningkatkan Hasil Belajar IPA Fisika Siswa Melalui Pembelajaran Kooperatif Tipe Student Teams Achievement Division (STAD)
}

\author{
Geulis Sitaresmi Agrin, M. Arifuddin, Sarah Miriam \\ Program Studi Pendidikan Fisika FKIP Universitas Lambung Mangkurat \\ sitaresmiagrin@gmail.com
}

\begin{abstract}
ABSTRAK: Hasil belajar IPA fisika siswa kelas VIII B SMP Negeri 31 Banjarmasin rendah. Oleh karena itu, dilakukan penelitian untuk meningkatkan hasil belajar IPA fisika siswa. Penelitian ini bertujuan untuk mendeskripsikan (1) keterlaksanaan RPP kooperatif tipe STAD, (2) peningkatan hasil belajar siswa setelah mengikuti pembelajaran kooperatif tipe STAD, (3) peningkatan keterampilan sosial siswa selama pembelajaran kooperatif tipe STAD. Jenis penelitian adalah penelitian tindakan kelas menggunakan model Kemmis dan Taggart yang terdri dari 2 siklus. Subjek penelitian adalah siswa kelas VIII B SMPN 31 Banjarmasin. Data diperoleh melalui pengamatan dan tes hasil belajar. Data dianalisis secara deskrptif kualitatif dan kuantitatif. Hasil penelitian menunjukkan bahwa: (1) adanya peningkatan keterlaksanaan RPP secara keseluruhan dari 71,29\% menjadi $86,20 \%$, (2) peningkatan ketuntasan hasil belajar siswa setiap siklus yaitu 68,97\% menjadi 96,55\%, dan (3) keterampilan sosial siswa selama pembelajaran kooperatif tipe STAD berkategori aktif. Diperoleh kesimpulan bahwa pembelajaran koperatif tipe STAD dapat meningkatkan hasil belajar IPA fisika siswa kelas VIII B SMP Negeri 31 Banjarmasin.
\end{abstract}

Kata kunci : Kooperatif, STAD, hasil belajar.

\begin{abstract}
The learning outcomes of physics subject in students grade VIII B SMP Negeri 31 Banjarmasin are low. Therefore, conducted a study to improve the learning outcomes of natural sciences physics subject. The aims of this research are to describe(1) the implementation of lesson plan of cooperative learning STAD type (2) improvement of student learning outcomes after learning cooperative learning STAD type (3)improvement of student social skills during cooperative learning STAD type. This research used a model of action research Kemmis and Taggart consisting of 2 cycles. The subject is a student of class VIII B SMPN 31 Banjarmasin. The instrument of collecting data are observation and learning outcome test. Data has analysed according to qualitative an quantitative descriptive. This research shows that:(1) the implementation of lesson plan improved in a totality from $71,29 \%$ become $86,20 \%$, (2) students learning outcome improved each cycle from 68,97\%, and (3) become 96,55\%andstudents social skills during cooperative learning STAD type categorized active. Be concluded that cooperative learning STAD type can improve the learning outcome physics science class VIII B SMP Negeri 31 Banjarmasin.
\end{abstract}

Keywords: Cooperative, STAD, Learning Outcomes. 


\section{PENDAHULUAN}

Pelajaran IPA di sekolah seharusnya menjadi mendengar siswa mempelajari alam sekitar juga diri sendiri serta mengembangkan dan menerapkan di dalam kehidupan seharihari,yang berdasar pada metode ilmah. Pemblajaran IPA berfokus pada praktek agar siswa mampu memaham alam sekitar melalui jalan mencari dan melakukan sehinga memungkinkan siswa memperoleh pemahaman yang lebih mendalam. (Suyidno \& Jamal, 2012).

Kenyataannya di lapangan, pada umumya guru bertugas mentransfer pegetahuan sedangkan siswa hanya menerima transfer pengetahuan dari guru saja.pembelajaran IPA dilakukan dalam bentuk satu arah dimana guru lebih banyak ceramah di hadapan siswa sementara siswa mendengarkan. Hal ini disebabkan karena terlalu mementingkan hasil atau nilai akhir saja tanpa memperhatikan proses pembelajaran di dalam kelas

Fakta dari hasil observasi pendahuluan diketahui bahwa nilai ratarata UAS IPA siswa semester ganjil tahun ajaran 2016/2017 hanya sebesar 43,79. Hal ini menunjukkan bahwa nilai tersebut berada di bawah standar ketuntasan minimum. tidak ada tuntas dari seluruh siswa yang berjumlah 29 siswa,

Salah satu faktor rendahnya hasil belajar IPA adalah siswa kurang terlibat pada proses belajar seperti: 1) siswa hanya menerima transfer pengetahuan dari guru saja, proses pembelajaran masih berpusat pada guru, metode penyampaian didominasi dengan ceramah, 2) kurangnya keberanian dan kesempatan siswa untuk bernteraksi dengan guru dan interaksi siswa dengan siswa untuk berpartsipasi dalam kegiatan belajar mengajar, 3) kurangnya keaktifan siswa dalam mengajukan dan menjawab pertanyaan serta mengemukakan pendapatnya.

Sebanyak 29 orang siswa kelas VIII B SMP Negeri 31 Banjarmasn terdiri dari 18 perempuan dan 11 laki-laki. Siswa kelas VIII B memiliki rentang usia 12-13 tahun. Dari rentang usia ini berarti siswa kelas VIII B dapat menangani situasi hipotesis, dan proses berpikir mereka semakin logis dan tidak lagi bergantung pada hal-hal yang langsung dan nyata. Siswa kelas VIII B menyukai kegiatan yang menyibukkan secara fisiik, lebih mudah mengingat apa yang dilihat dan dipraktikkan langsung dari pada apa yang didengar, dan tidak dapat duduk diam di suatu tempat untuk waktu yang lama. Beberapa siswa kelas VIII B juga sulit bergaul dengan teman 
sekelasnya, terutama dengan teman yang memiliki tingkat prestasi dan status sosial yang berbeda.

Materi IPA yang digunakan pada penelitian ini adalah cahaya dan alat-alat optik. Materi cahaya dan alat-alat optik ini dipilih karena beberapa pertimbangan. Pertama, menyesuaikan dengan pembelajaran yang berlangsung di kelas VIII B SMP Negri 31 Banjarmasin. Kedua, materi cahaya dan alat-alat optik ini contoh-contohnya dapat dikaitkan dengan kehidupan sehari-hari, dan ketiga materi ini memerlukan kemampuan kerjasama dalam melakukan percobaan untuk membangun pengetahuan siswa dan meningkatkan partisipasi siswa didalam kelas. Dalam pembelajaran materi cahaya dan alat-alat optik hendakya siswa dapat berperan aktif dalam kegiatan belajar mengajar agar siswa dapat meningkatkan hasil belajar mereka, hal ini dapat dcapai salah satunya melalui pembelajaran kooperatif.

Berdasarkan permasalahan, karakterstik siswa dan materi, maka diperlukan model pembelajaran yang tepat untuk mengatasinya. Hasil belajar siswa dalam mata pembelajaran IPA diharapkan meningkat dengan Model Pembelajaran Kooperatif tipe STAD.
Metode pembelajaran kooperatif yang paling sederhana, ialah pembelajaran kooperatf tipe STAD merupakan salah satu model untuk pemulaan bagi para guru yang mengunakan pendekatan koopertaif yang paling baik, metode yang paling banyak diaplikasikan juga merupakan pembelajaran kooperatif, sudah dpakai dari kelas dua sampai kelas sebelas. (Slavin, 2005). Kelebihan pembelajaran kooperatif tipe STAD menurut Ibrahim, dkk. (2000), adalah 1) para siswa mendapatkan kesempatan untuk bekerja sama dengan siswa lain; 2) pelajaran yang disampaikan dapat dikuasai; 3) dalam proses belajar mengajar siswa salng ketergantungan positif 4)siswa mengisi satu sama lain dengan siswa lain (Majid, 2014).

Prasetyaningtyas membuktikan bahwa Pembelajaran Kooperatif tipe ini dapat meningkatkan nlai akhir siswa. Pemahaman konsep pada siklus I adalah $61 \%$. Terjadi peningkatan Siklus II 18,3\% jadi 79,3\%. Posstest menunjukkan presentasi sebesar 89,7\% dengan kategori tnggi.

Atas dasar hal tersebut, peneliti bermaksud untuk meneliti tentang upaya meningkatkan nilai siswa SMPN 31 Banjarmasin Kelas VIII B melalui penerapan model pembelajaran 
kooperatf tipe Student Teams

Achievement Divisions.

Perumusan masalah secara umum dalam penelitian ini ialah bagaimana cara meningkatkan hasil belajar IPA Fisika murid kelas VIII B SMP Negeri 31 Banjarmasin melalui pembelajaran kooperatif tipe Student Teams Achievement (STAD)?. Berdasarkan rumusan masalah di atas, dapat diidentifikasi beberapa penelitian sebagi berkut: (1) Bagaimanakah keterlaksanan RPP kooperatif tipe STAD?

Bagamanakah peningkatan hasil belajar siswa setelah mengikuti pembelajaran kooperatif tipe STAD? (3) Bagaimakah peningkatan keterampilan sosial siswa selama pembelajaran kooperatif tipe STAD?.

\section{Mendeskripsikan}

cara meningkatkan nilai IPA Fiska iswa kelas VIII B SMPN 31 Banjarmasin dengan model pembelajaran koperatif tipe STADadalah tujuan penelitian ini secara umum. Tujuan penelitian khususnya adalah seperti antara lain : (1) Mendeskripsikan keterlaksanan RPP kooperatf tipe STAD;

Mendeskripskan kenaikan hasil belajar siswa setelah mengikuti pembelajaran kooperatf tipe STAD;

Mendeskiripsikan peningkatan keterampilan sosial selama pemblajaran koperatif tipe STAD.

\section{KAJIAN PUSTAKA}

Hasil belajar adalah suatu nilai yang diperoleh dengan mengukur tujuan pembelajaran secara individual maupun klasikal menentukan kompetensi siswa (Yahyana, Arifuddin, \& Miriam, 2017). Untuk mengukur sejauh mana siswa menguasai pelajaran yang telah diajarkan dlakukanlah hasil belajar (Dewantara, Jamal, \& An'nur, 2013).Mappeasse (2009) menyatakan kemampuan baik bersifat kognitif, afektif, maupun psikomotorik yang semuanya ini dperoleh melalui proses belajar mengajar mrupakan hasil belajar. Daud (2012) berpendapat hal-hal yang dicapai seseorang setelah melalui proses belajar disebut hasil belajar.

Hamdani (2014) bependapat model pembelajaan kooperatif menciptakan sebuah revolusi pembelajaran. Siswa dapat dimotivasi melalui model pembelajaran, memanfatkan energi sosial, dan tanggung jawab. Menurut Chasanah, Sinon \& Widyanngsih (2016) salah satu model pembelajaran yang berpusat pada peserta didik model pembelajaran kooperatif. Peserta didik belajar secara bertim untuk menuntaskan masalah bersama-sama sehigga peserta didik meningkatkan sikap positif terhadap IPA. Model kooperatf juga dapat melatih siswa dalam bekerja sama, menghargai kemampuan orang 
lain, serta dapat meningkatkan tanggung jawab siswa (Nurkhatimah et al., 2014).

Talamoa, Kundera \& Dhafri (2016) menyatakan STAD tipe dari pembelajaran koperatif yang paling sederhana yang paling mudah diterapkan. Pada model ini siswa memahami gejala fisik dengan di beri membicarakan pengamatan dan ide mereka. Menurut Aqib (Gumay, Kordasih \& Mulyanto,2016) berpendapat bahwa untuk guru yang baru mulai menggunakan pendekatan kooperatif dalam kelas model dalam pembelajaran kooperatif tipe student yang sederhana dan baik ialah STAD. Keterampilan sosial adalah keahlian seseorang melakukan komunikasi dengan orang lain sesuai stuasi dan kondisi yang ada baik secara verbal maupun nonverbal (Kurniasih, An'nur, \& Wati, 2014).

Maryani \& Syamsudin (2009) menyatakan keterampilan sosial adalah keterampilan untuk berinteraksi, berkomuniikasi dan berpartisipasi dalam kelompok. Menurut Vygotski terbentuknya ide baru dan memperkaya perkembangan intelektual siswa dipicu oleh interaksi sosial siswa sehingga sebaiknya interaksi dengan orang dewasa atau teman sebaya yang lebih mampu dari diri ini (Ulansari, 2012).

\section{METODE PENELITIAN}

Penelitian ini merupakan penelitian tindakan kelas (PTK). PTK bertujuan untuk memperbaiki atau meningkatkan mutu proses pembelajaran di kelasnya merupakan cara merancang, melaksanakan, mengamati, dan merefleksikan tindakan kegiatan ilmiah yang dilakukan oleh guru di kelasnya.

Penelitian ini dilakukan sebanyak dua siklus yang setiap siklus terdiri dari tahap perencaanaan tindakan (plan), pelaksanaan (act), pengamatan (observe) dan refleksi (reflect). Kemmis dan. Taggart adalah model yang digunakan di Penelitian Tindakan Kelas ini.

Penelitian ini dilaksanakan pada semester 2, yaitu pada bulan Mei 2017. Dalam penelitian ini yang menjadi subjek penelitian adalah siswa kelas VIII B yang terdiri dari 29 siswa dengan komposisi perempuan 18 siswa dan lakilaki 11 siswa. Objek penelitian adalah hasil belajar IPA fisika menggunakan model pembelajaran kooperatif tipe STAD.

Data penelitian kuantitatif diperoleh dengan cara pengumpulan dan berupa tes tertulis yang diberikan pada individu dalam setiap siklus, sedangkan data penelitian kualitatif diperoleh dari observasi keterampilan sosial siswa melalui pengamatan pada kegiatan siswa 
dalam partisipasi kelompok dan dengan meggunakan lembar observasi.

Teknik korelasi product momentyang digunakan untuk mengetahui kesejajaran adalah yang dikemukakan oleh Pearson (Arikunto, 2009).

$$
\mathrm{r}_{\mathrm{xy}}=\frac{\Sigma_{x y}}{\sqrt{\left(\Sigma_{x}^{2}\right)\left(\Sigma_{y}{ }^{2}\right)}}
$$

Keterangan:

$r_{x y}=$ koefisien korelasi

$\Sigma_{x y}=$ jumlah perkalian $\mathrm{x}$ dengan $\mathrm{y}$

$x^{2}=$ kuadrat dari $\mathrm{x}$

$y^{2}=$ kuadrat dari $\mathrm{y}$

$$
\text { Pengamatan keterlaksanaan }
$$

Rencana Pelaksnaan Pembelajaran

dlakukan oleh dua pengamat dengan memberikan tanda $(\sqrt{ })$ pada kolom keterlaksanan dengan kategori tidak baik, kurang baik, baik dan sangat baik. Untuk mengetahui presentase keterlaksanan RPP, digunakan rumus:

$$
K=\frac{f}{N} \times 100 \%
$$

Keterangan:

$K=$ Persntase keterlaksanaan.

$f=$ rata-rata skor per fase ketelaksanaan.

$N=$ skor rata-rata maksmum

Persentase keterampilan sosial siswa dapat dihitung mengunakan:

$$
P_{k}=\frac{R}{n} \times 100 \%
$$

Keterangan:

$P_{k}=$ Pesentase keterampilan sosal siswa $R=$ Rata-rata keterampilan sosial siswa dilihat dri pengamat 1 dan pengamat 2

$n=$ jumlah keterampilan yang diamat

Ketuntasan hasil belajar secara klasikal dihitung dengan menggunakan rumus:

$$
K K=\frac{\Sigma S}{N} \times 100 \%
$$

Keterangan:

$K K=$ Ketuntasan klasikal.

$\Sigma S=$ jumlah siswa tuntas secara individual

$N=$ jumlah siswa

\section{HASIL DAN PEMBAHASAN \\ Keterlaksanaan RPP}

Tingkat ketercapaian rencana pelaksanan pembelajaran menggunakan model pembelajaran koperatif yang damati melalui lembar observasi dinyatakan dengan persentasi dan dikonversi dalam kategor sangat kurang, kurang, cukup, bak, dan sangat baik disebut Keterlaksanaan RPP diamati pengamat selama pembelajaran berlangsung. Hasil observasi keterlaksanan RPP siklus I dapat dilhat pada Tabel 1.

Tabel 1 Keterlaksanan RPP siklus I

\begin{tabular}{ccccc}
\hline \multirow{2}{*}{ Fase } & \multicolumn{2}{c}{ Petemuan I } & \multicolumn{2}{c}{ Pertemuan II } \\
\cline { 2 - 5 } & $\begin{array}{c}\text { Rata-rata } \\
\text { per fase }\end{array}$ & Kategori & $\begin{array}{c}\text { Rata-rata } \\
\text { per fase }\end{array}$ & Kategori \\
\hline 1 & 2,90 & Baik & 3,00 & Baik \\
2 & 2,67 & Cukup & 2,67 & Cukup \\
3 & 2,88 & Baik & 3,00 & Baik
\end{tabular}




\begin{tabular}{ccccc} 
Lanjutan Tabel 1 & \multicolumn{5}{c}{} \\
\hline 4 & 2,50 & Cukup & 2,75 & Cukup \\
5 & 2,90 & Baik & 3,00 & Baik \\
6 & 3,00 & Baik & 3,00 & Baik \\
7 & 2,67 & Cukup & 3,00 & Baik \\
$\begin{array}{c}\text { Rata-rata } \\
\text { Keseluruhan }\end{array}$ & 2,79 & Cukup & 2,92 & Baik \\
\hline
\end{tabular}

Pada siklus I, guru memilliki kendala dalam pengelolaan waktu di dalam kelas. Hal tersebut kendala pada saat mengorganisasikan siswa ke dalam kelompok belajar dikarenakan siswa yang tidak tertib saat mencari anggota kelompok lain, siswa lambat berkumpul pada kelompoknya masing-masing dan juga karena banyak kelompok yang kesulitan saat berdiskusi pada saat melakukan percobaan, siswa lebih menyukai berkumpul dengan teman akrabnya dalam berkelompok. Para siswa kesulitan saat berdiskusi karena banyak kegiatan praktikum yang dikerjakan sedangkan siswa belum terbiasa melakukan percobaan. Akibatnya guru lebih banyak menghabiskan waktu pada fase membimbing kelompok bekerja dan belajar. Kendala lainnya adalah kurang mampunya peneliti selaku guru untuk mengelola kelas dan mengarahkan siswa untuk berdiskusi dengan tenang saat proses belajar mengajar berlangsung.Dan masih ada sebagian kelompok yang belum memahami langkah-langkah pembelajaran kooperatif secara menyeluruh.Berdasarkan kekurangan pada siklus I tersebut, maka upaya yang dilakukan peneliti adalah meningkatkan pengawasan dan memberikan waktu secara individual kepada siswa yang kesulitan.

Adapun hasil observasi keterlaksanan RPP pada sklus II dapat dilihat dalam Tabel 2.

Tabel 2 Keterlaksanan RPP siklus II

\begin{tabular}{ccccc}
\hline \multirow{2}{*}{ Fase } & \multicolumn{2}{c}{ Pertemuan I } & \multicolumn{2}{c}{ Pertemuan II } \\
\cline { 2 - 5 } & Rata-rata perfase & Kategori & Rata-rata perfase & Kategori \\
\hline 1 & 3,40 & Baik & 3,70 & Sangat baik \\
2 & 2,83 & Baik & 3,67 & Sangat baik \\
3 & 3,00 & Baik & 3,88 & Sangat baik \\
4 & 3,00 & Baik & 3,50 & Sangat baik \\
5 & 3,00 & Baik & 3,80 & Sangat baik \\
6 & 3,00 & Baik & 4,00 & Sangat baik \\
7 & 3,67 & Sangat baik & 3,83 & Sangat baik \\
Rata-rata & 3,13 & Baik & 3,77 & Sangat baik \\
\hline
\end{tabular}


Berdasarkan upaya perbaikan yang dilaksanakan pada siklus II terbukti dengan meningkatnya persentase ratarata keterlaksanaan RPP pada siklus II.Persentase rata-rata keterlaksanaan RPP mengalami peningkatan dari siklus I ke siklus II. Rata-rata keterlaksanaan RPP mengalami peningkatan dari $71,29 \%$ pada siklus I menjadi86,20\% pada siklus II.

Berdasarkan uraian tersebut, dapat disimpulkan bahwa rata-rata keterlaksanaan RPP sudah mengalami peningkatan dari siklus I ke siklus II. Hal ini sudah memenuhi indikator keberhasilan dalam penelitian

\section{Ketuntasan Hasil Belajar}

Hasil belajar adalah pencapaian kriteria atau penguasaan konsep yang telah diterapkan bagi setiap unit bahan ajar yang ditunjukkan dengan hasil belajar siswa yang dukur dengan meggunakan tes dan dinyatakan dengan tuntas atau tidak tuntas.

Tabel.3 Keterlaksanaan RPP siklus II

\begin{tabular}{lccc}
\hline \multirow{2}{*}{ No } & \multirow{2}{*}{ Ketuntasan } & \multicolumn{2}{c}{ Siklus } \\
\cline { 3 - 4 } & & I & II \\
\hline 1 & Tuntas & 20 & 28 \\
2 & Tidak Tuntas & 9 & 1 \\
Ketuntasan klasikal & $68,97 \%$ & $96,55 \%$ \\
\hline
\end{tabular}

Penelitian ini mengunakan model pembelajaran koperatif tipe STAD dan didapatkan ketuntasan hasil belajar siswa scara klasikal meningkat dari
Hasil belajar siswa diperoleh dari tes hasil belajar yang diadakan setiap akhir siklus dengan menganalisis ketuntasaan hasil belajar siswa scara indvidual dan klasikal yang dgunakan untuk menguku kemampuan pemahaman sswa terhadap pembelajaran.

Tes pada sklus I sebanyak 8 butir soal. Setiap soal di kategrikan berdasakan taksonom Blom yang direvisi. Butir soal 1, 2, 3, 4, 5 dan 6 termasuk aspek $\mathrm{C} 2$, butr soal 7 termasuk aspek $\mathrm{C} 3$, dan butir soal 8 termasuk aspek $\mathrm{C} 4$.

Hasil belajar dalam proses pembelajaran dikatakan tuntas jika mendapat $\geq 70$ dan tidak tuntas jika $<$ 70. Hasil ketuntasan klasikal dihitung dar jumlah siswa yang tuntas mencapa nlai KKM yang diihat dari jumlah sswa secara keseluruhan. Hasil belajar siswa dapat diihat dalam Tabel 3. 
Ketuntasan hasil belajar pada siklus II meningkat menjadi $96,55 \%$, artinya hanya ada satu siswa yang tidak tuntas dari 29 siswa. Ketuntasan ini sudah memenuhi indikator keberhasilan yaitu minimal 70\%. Peningkatan hasil belajar ini disebabkan siswa telah terbiasa bekerja sama dalam kelompok pada model pembelajaran kooperatif tipe STAD. Hal ini sejalan dengan pedapat Ibrahim (Majid, 2014) yatu kelebihan model pembelajaran kooperatif tipe STAD adalah siswa dapat menguasai pelajaran yang disampaikan. Menurut Vygotsky (Khodijah, 2014), dengan berinteraksi dengan orang lain, anak memperbaiki pemahaman dan pengetahuan mereka dan membantu membentuk pemahaman tentang orang lain.

Berdasarkan uraian di atas, dapat disimpulkan bahwa model pembelajaran koperatif tipe Student Teams
Achievement Division (STAD) dapat meningkatkan hasil belajar siswa terbukti dengan banyakya siswa yang dapat mencapai nilai KKM yng sudah dtentukan.

\section{Keterampilan Sosial Siswa}

Keterampilan sosial siswa adalah frekuensi aspek kooperatif (berada dalam tugas, mengambl giliran dan berbagi tugas, mendorong partsipasi teman untuk memberi pendapat/ide, mendegarkan dengan aktif, betanya) yang muncul pada saat proses pembelajaran yang diukur dengan menggunakan lembar pengamatan keterampilan kooperatif siswa dinyatakan dengan persentasi dan dikonversi dalam kategori tidak aktif, kurang aktif, cukup aktif, aktif, dan sangat aktif. Hasil pengamatan keteramplan sosial siswa pada siklus I dinyatakan dalam Tabel 4.

Tabel 4 Keteramplan sosial siswa pada siklus I

\begin{tabular}{clcc}
\hline No & \multicolumn{1}{c}{ Aspek yang diamati } & Persentase & Kategori \\
\hline 1 & Berada dalam tugas & $59,9 \%$ & Cukup aktif \\
2 & Mengambil giliran dan berbagi tugas & $50,8 \%$ & Cukup aktif \\
3 & Mendorong partsipasi teman untuk & $59,2 \%$ & Cukup aktif \\
& memberi pendapat/ide & $60,8 \%$ & Aktif \\
4 & Mendengarkan dengan aktif & $64,2 \%$ & Aktif \\
5 & Bertanya & & \\
\hline
\end{tabular}

Keterampilan sosial pada siklus I teman yang tidak akrab dan tidak seluruhnya aktif, siswa belum berkemampuan lebih tinggi. Dari tabel terbiasa berkelompok terutama kepada diatas dapat dikatakan keterampilan sosial 
pada siklus I termasuk dalam kategori keterampilan siswa pada siklus II dapat cukup aktif. Hasil pengamatan dilhat pada Tabel 5.

Tabel 5 Keterampilan sosial siswa pada siklus II

\begin{tabular}{clcc}
\hline No & \multicolumn{1}{c}{ Aspek yang diamati } & Persentase & Kategori \\
\hline 1 & Berada dalam tugas & $80,0 \%$ & Cukup aktif \\
2 & Mengambil giliran dan berbagi tugas & $75,0 \%$ & Cukup aktif \\
3 & Mendorong partsipasi teman untuk & $76,6 \%$ & Cukup aktif \\
& memberi pendapat/ide & $72,5 \%$ & Aktif \\
4 & Mendengarkan dengan aktif & $75,8 \%$ & Aktif \\
5 & Bertanya & & \\
\hline
\end{tabular}

Berdasarkan data yang diperoleh selama penelitian menunjukkan bahwa terjadi peningkatan keterampilan sosial siswa di setiap pertemuan pada siklus I dan siklus II. Ini dikarenakan siswa semakin terbiasa belajar dalam kelompok-kelompok dan semakin antusias mengikuti pelajaran. Hal ini sejalan dengan penelitian yang dilakukan oleh Ulansari (2012) yang membuktikan bahwa Pembelajaran Kooperatif tipe STAD dapat meningkatkan keterampilan sosial siswa. Hal ini membuktikan bahwa pembelajaran kooperatif tipe STAD dapat meningkatkan keterampilan sosial siswa. Menurut Suyidno \& Jamal (2012), di samping model pembelajaran koperatif dikembangkan untuk mencapai hasil belajar akademik, model pemblajaran koperatif juga efektif untuk mengembangkan keterampilan sosial siswa. Dalam pembelajaran kooperatif, siswa terlibat aktif pada proses pembelajaran sehingga memberikan dampak positif terhadap interaksi dan komunikasi, serta dapat meningkatkan prestasi siswa.

\section{SIMPULAN}

Upaya meningkatkan hasil belajar IPA fisika siswa kelas VIII B SMP Negeri 31 Banjarmasn dengan model pembelajaran kooperatif adalah memotivasi siswa dan menyampaikan tujuan, menyajikan informasi, mengorganisasikan siswa kepada kelompok-kelompok belajar, membimbing kelompok bekerja dan belajar,evaluasi, dan memberikan penghargaan.

Berdasarkan simpulan di atas, dapat diuraikan temuan sebagai berikut.

(1) Rata-rata keterlaksanaan RPP secara keseluruhan pada siklus I 
dan siklus II meningkat dari $71,29 \%$ menjad $86,20 \%$.

(2) Hasil belajar siswa secara klasikal pada siklus I dan siklus II meningkat dari $68,97 \%$ menjadi $96,55 \%$.

(3) Keterampilan sosial siswa memenuhi indikator keberhasilan. Keterampilan sosial pada siklus I dan sikus II meningkat dengan kategori aktif.

\section{DAFTAR PUSTAKA}

Arikunto, S. (2009). Dasar-Dasar Evaluasi Penddikan. Jakarta: PT. Bumi Aksara.

Chasanah, U. U., Snon, I. L., \& Widyaningsih, S. W. (2016). Penerapan Model Koperatif Tipe STAD (Student Team Achivement Divison) dengan Media Peta Konsep untuk Meningkatkan Hasil Belajar IPA Peserta Didik Kelas IX A SMP Negeri 19 Manokwari. Pancaran Pendidikan, 5(2), 25-38.

Daud, F. (2012). Pengaruh kecerdasan emosional (EQ) dan motivasi belajar terhadap hasil belajar biologi siswa SMA 3 Negeri kota palopo. Jurnal Pendidikan dan Pembelajaran (JPP), 19(2), 243255.

Dewantara, D., Jamal, M. A., \& An'nur, S. (2013). Meningkatkan Hasil Belajar Siswa Kelas XI IPA-1 SMA Negeri 1 Jorong Melalui Pembelajaran Koperatif Tipe Somatc Audtory Visual and Intelectual pada Pokok Bahasan Impuls dan Momentum. Berkala
Ilmiah Pendidikan Fisika, 1(2), 159-168.

Gumay, O. P. U., Kodarsih, E., \& Mulyanto, A. B. (2016). Pengaruh Model Pembelajaran Koperatif Tipe Student Teams Achievement Division (Stad) Terhadap Hasil Belajar Fisika Siswa Kelas X Sma Negeri 2 Muara Beliti Tahun Pelajaran 2015/2016. In Prosiding Seminar Nasional Fisika (EJournal) (Vol. 5, pp. SNF2016EER).

Hamdani, D. (2014). Penerapan Model Kooperatf Tipe STAD dengan Microsoft Power point untuk Menngkatkan Hasil Belajar Siswa Kelas VIII B SMP Negeri 5 Kota Bengkulu. Exacta, 8(1): 15-16.

Khodijah, N. (2014). Psikologi Pendidikan. Jakarta: PT Raja Grafindo Persada.

Kurniasih, D., An'nur, S., \& Wati, M. (2014). Meniingkatkan Hasil Belajar dan Keterampilan Sosial Siswa Melalui Penerapan Pembelajaran Koperatif Tipe Team Game Tournamen (TGT). Berkala Ilmiah Pendidikan Fisika, 2(3), 281-291.

Majid, A. (2014). Penilaian Autentik Proses dan Hasil Belajar. Bandung: PT Remaja Rosdakarya.

Mappeasse, M. Y. (2009). Pengaruh cara dan motivasi belajar terhadap hasil belajar programable logic controller (PLC) siswa kelas III jurusan listrk SMK Negeri 5 Makassar. Jurnal Medtek, 1(2), 1-6.

Maryani, E., \& Syamsudin, H. (2009). Pengembangan Program Pemblajaran meningkatkan 
Keterampilan sosial. Jurnal Penelitian, 9(1).

Nurkhatimah, N., Zainuddin, Z., \& Hartini, S. (2014). Meningkatkan Hasl Belajar Siswa Melalui Penerapan Model Pemblajaran Koperatif Tipe Take and Give. .Berkala Ilmiah Pendidikan Fisika, 2(2), 110-122.

Prasetyaningtyas, S. (2015). Penerapan Model Pembelajaran Koperatif Stad untuk Meningkatkan Keaktifan dan Prestasi Belajar IPA pada Materi Pewarisan Sifat Siswa Kelas IX SMP Negeri 1 Semin. In Prosiding SNPS (Seminar Nasional Pendidikan Sains) (Vol. 2, pp. 430442).

Slavin, R E. (2005). Cooperative Learning (Narulta Yusron, Penerjemah). Bandung: Penerbit Nusa Media.

Suyidno dan Jamal, M A. (2012). Strategi Belajar Mengajar. Banjarmasin: P3AI Universitas Lambung Mangkurat.
Talamoa, N. A., Kundera, I. N., \& Dhafir, F. (2016). Penerapan Model Pembelajaran Kooperatif Tipe STAD (Student Teams Achievement Division) Untuk Meningkatkan Hasil Belajar Siswa Pada Mata Pelajaran IPA di Kelas V SDN 14 Ampana. Jurnal Kreatif Tadulako Online, 4(4).

Ulansari, I. (2012). Keterampilan Sosial Siswa Melalui Pembelajaran Kooperatif Tipe Stad Pada Materi Pokok Larutan Penyangga Di Sman 1 Sumberejo Bojonegoro (Students'social Skill Through Cooperative Learning Model Stad Type On Buffer Solution Subject At Sman 1 Sumberrejo B. Unesa Journal Of Chemical Education, 1(1).

Yahyana, Z., Arifuddin, M., \& Miriam, S. (2017). Menngkatkan Hasil Belajar Siwa Kelas VIII C SMP Negri 26 Banjarmasn Topk Cahaya dan Alat-Alat Optik Melalui Pengajaran Langsung. Berkala Ilmiah Pendidikan Fisika, 5(3), 297-308. 